\title{
Anti-biofilm properties exhibited by different types of monofloral honey
}

\author{
Filomena Nazzaro ${ }^{1 *}$, Florinda Fratianni ${ }^{1}$, Antonio d'Acierno ${ }^{1}$, Maria Neve Ombra ${ }^{1}$, Lucia Caputo ${ }^{2}$, \\ Raffaele Coppola ${ }^{3}$ and Vincenzo De Feo ${ }^{2}$ \\ ${ }^{1}$ Institute of Food Science, CNR-ISA, Via Roma 64, 83100, Avellino, Italy; fratianni@isa.cnr.it (FF); \\ dacierno.a@isa.cnr.it (A.d.A.); marianeve.ombra@isa.cnr.it (MNO) \\ ${ }^{2}$ DiFARMA, University of Salerno, via Giovanni Paolo II, Fisciano (SA) Italy; caputo@unisa.it (LC); \\ defeo@unisa.it (VDF) \\ ${ }^{3}$ DiAAA, University of Molise, Via de Sanctis snc, 86100, Campobasso, Italy; coppola@unimol.it (RC) \\ * Correspondence: filomena.nazzaro@isa.cnr.it; Tel.: (+390825299102 (FN) \\ + Presented at the First International Electronic Conference on Microbiology, 02-30 November 2020, \\ Available online: https://ecm2020.sciforum.net/ \\ Published: 02 November 2020
}

\begin{abstract}
Our aim was to evaluate the susceptibility of bacterial biofilm formation and the metabolic changes occurring to the bacterial cells to the ivy, strawberry tree, lavender, sulla and tree of heaven monofloral honeys. Listeria monocytogenes was the most sensitive bacteria with percentages of biofilm inhibition up to $72.20 \%$. Pseudomonas aeruginosa was less sensitive, but tree of heaven and sulla honey caused an inhibition of biofilm up to $40.41 \%$ and $35.85 \%$, respectively. The tree of heaven honey acted on the P. aeruginosa metabolism (75.24\%). Staphylococcus aureus, majorly resistant to the biofilm-inhibitory action of the honey, was more sensitive at the metabolic level $(61.63 \%$ inhibition in the presence of the tree of heaven honey).
\end{abstract}

Keywords: Honey; Biofilm; Pseudomonas aeruginosa; Listeria monocytogenes; Staphylococcus aureus

\section{Introduction}

Biofilm formation represents a self-protective mechanisms of bacteria where bacteria aggregate to create a complex structure so to resist to the harsh conditions. This gives rise to an increase of their surface attachment ability, and a higher population density, with the production of extracellular polymeric substances (EPS) and with a subsequent range of physical, metabolic and chemical processes which take place also to an increase of pathogenicity. [1]. The formation of biofilm determines higher tolerance to the conventional antimicrobial agents and resistance to phagocytosis so that they become more difficult to eradicate from living hosts [2]. The problem has determined intensive efforts from scientists to develop better strategies to prevent, inhibit and demolish biofilm formation. Since prehistoric age, honey has been used in curing ailments, in preventing the onset of ailments [3] and in folk medicine it is used to treat some types of infections. In last decades, the modern clinical practices, cost and difficulty of chronic wound care asked for better and cost effective remedies [4]. Honey has demonstrated to be effective in inhibiting the formation of biofilm of Klebsiella pneumoniae and Pseudomonas aeruginosa [5], oral streptococci [4,6], Proteus mirabilis and Enterobacter cloacae [7]. Among monofloral types, manuka honey is one of the most studied, demonstrating its capacity to inhibit the biofilm formation of Clostridium difficile [8], Staphylococcus aureus [9] and Candida albicans [10] among all. Aim of our work was to evaluate the susceptibility of bacterial biofilm formation and the metabolic changes occurring to the bacterial cells to the ivy, strawberry tree, lavender, sulla and tree of heaven Italian monofloral honeys. We considered three 
bacteria, Listeria monocytogenes, Pseudomonas aeruginosa and Staphylococcus aureus as tester strains, which infections are becoming more difficult to treat as further evolution of drug resistance occurs within them.

\section{Material and methods}

Different types of Italian organic monofloral honey were purchased by an Italian company (Thun, Trento, Italy), The Luria Bertani culture medium, PBS, DMSO and MTT were provided by Sigma (Milano, Italy).

\subsection{Microorganisms and Culture Conditions}

Listeria monocytogenes ATCC 7644, Pseudomonas aeruginosa DSM 50071 and Staphylococcus aureus subsp. aureus ATCC 25923 were used as test bacterial strains. Bacteria were cultured in LB broth for $18 \mathrm{~h}$ at $37{ }^{\circ} \mathrm{C}$ and $80 \mathrm{rpm}$ (Corning LSE, Pisa, Italy).

\subsection{Minimal Inhibitory Concentration (MIC)}

The MIC values were calculated using the resazurin microtiter-plate assay [11]. Multiwell plates were prepared in triplicate and incubated at $37^{\circ} \mathrm{C}$ for $24 \mathrm{~h}$. The lowest concentration at which a color change occurred (from dark purple to colorless) revealed the MIC value.

\subsection{Biofilm Inhibitory Activity}

The effect of the honeys on bacterial ability to form biofilm was assessed according to the method of $\mathrm{O}^{\prime}$ Toole and Kolter [12] in flat-bottomed 96-well microtiter plates, using two sub-inhibitory volumes of honey (previously dissolved in sterile PBS), precisely $5.71 \mu \mathrm{L} / \mathrm{mL}$ and $11.42 \mu \mathrm{L} / \mathrm{mL}$. The overnight bacterial cultures were adjusted to $0.5 \mathrm{McF}$ arland with fresh culture broth. Then, $10 \mu \mathrm{L}$ of the diluted cultures was distributed in each well, and the samples of the honeys and sterile LuriaBertani broth were added, to reach a final volume of $250 \mu \mathrm{L} /$ well. To avoid the evaporation of samples, microplates were then completely covered with parafilm tape, and incubated for $48 \mathrm{~h}$ at $37^{\circ} \mathrm{C}$. Planktonic cells were removed and the attached cells were gently washed twice with sterile physiological saline. $200 \mu \mathrm{L}$ of methanol was added to each well, and left for $15 \mathrm{~min}$ to fix the sessile cells. After discharge of methanol, each plate was placed under laminar flow cap until complete dryness of samples. The staining of the adhered cells was obtained through the use of $200 \mu \mathrm{L}$ of $2 \% \mathrm{w} / \mathrm{v}$ crystal violet solution to each well that was left for $20 \mathrm{~min}$. Wells were gently washed with sterile PBS and left to dry. The release of the bound dye was obtained through the addition of two hundred microliters of glacial acetic acid 20\% w/v. The absorbance was measured at OD = 540 nm (Varian Cary Spectrophotometer model 50 MPR, Cernusco sul Naviglio, Italy). The percent value of biofilm inhibition was calculated with respect to control (cells grown without the presence of the Eos, assuming for it $\mathrm{a} \%=0$ ). The average results from triplicate tests were taken for reproducibility.

\subsection{Metabolic Activity of Biofilm Cells}

The effect of two volumes, $5.71 \mu \mathrm{l} / \mathrm{mL}$ and $11.42 \mu \mathrm{l} / \mathrm{mL}$, of the honeys (prepared as above described) on the metabolic activity of biofilm cells, was evaluated through the MTT colorimetric method [13-14] using 96-well microtiter plates. The overnight bacterial cultures were adjusted to 0.5 McFarland and treated as previously described. Bacterial suspension, representing the planktonic cells, were removed after $48 \mathrm{~h}$ incubation. $150 \mu \mathrm{L}$ of sterile PBS and $30 \mu \mathrm{L}$ of $0.3 \%$ MTT (Sigma, Milan, Italy) were added in each well, keeping microplates at $37^{\circ} \mathrm{C}$. After $2 \mathrm{~h}$, the MTT solution was removed, two washing steps were performed gently with $200 \mu \mathrm{L}$ of sterile physiological solution, then $200 \mu \mathrm{L}$ of DMSO was added to let the dissolution of the formazan crystals, which were measured at $\mathrm{OD}=570 \mathrm{~nm}$ (Varian). Triplicate tests were carried out and the average results were taken for reproducibility 


\section{Results and Discussion}

The potential effect that the monofloral honeys had on the formation of biofilm of some pathogenic bacteria and on the metabolism of the bacterial cells included in the biofilm was assessed using sublethal amount of the samples. Results are shown in tables 1 and 2, respectively.

The results showed that the honeys exhibited a remarkable capacity to inhibit the formation of the bacterial biofilm.

Table 1. Inhibitory action of the different types of monofloral honey on the formation of biofilm. Results are reported as percent of inhibition respect to the control (which \% was assumed $=0$ ). They are the mean $( \pm \mathrm{SD})$ of three experiments. TH: Tree of heaven honey; I: Ivy honey; L: Lavender honey; S: Sulla honey: ST: Strawberry tree honey. LM: Listeria monocytogenes; PA: Pseudomonas aeruginosa; SA: Staphylococcus aureus.

\begin{tabular}{|c|c|c|c|c|c|c|c|c|c|c|}
\hline $\begin{array}{c}\text { CV test } \\
\% \text { of } \\
\text { biofilm } \\
\text { inhibition }\end{array}$ & $\begin{array}{c}\text { TH } \\
5.71 \\
\mu \mathrm{l} / \mathrm{ml}\end{array}$ & $\begin{array}{c}\text { TH } \\
11,42 \\
\mu \mathrm{l} / \mathrm{ml}\end{array}$ & $\begin{array}{c}I \\
5.71 \\
\mu \mathrm{l} / \mathrm{ml}\end{array}$ & $\begin{array}{c}I \\
11.42 \\
\mu \mathrm{l} / \mathrm{ml}\end{array}$ & $\begin{array}{c}\mathbf{L} \\
5.71 \\
\mu \mathrm{l} / \mathrm{ml}\end{array}$ & $\begin{array}{c}\mathrm{L} \\
11.42 \\
\mu \mathrm{l} / \mathrm{ml}\end{array}$ & $\begin{array}{c}S \\
5.71 \\
\mu \mathrm{l} / \mathrm{ml}\end{array}$ & $\begin{array}{c}S \\
11.42 \\
\mu \mathrm{l} / \mathrm{ml}\end{array}$ & $\begin{array}{c}\text { ST } \\
5.71 \\
\mu \mathrm{l} / \mathrm{ml}\end{array}$ & $\begin{array}{c}\text { ST } \\
11.42 \\
\mu \mathrm{l} / \mathrm{ml}\end{array}$ \\
\hline LM & $\begin{array}{l}65.82 \\
(2.81)\end{array}$ & $\begin{array}{l}66.07 \\
(1.57)\end{array}$ & $\begin{array}{c}53.65 \\
(1.35 \\
) \\
\end{array}$ & $\begin{array}{l}63.37 \\
(1.57)\end{array}$ & $\begin{array}{l}24.17 \\
(0.57)\end{array}$ & $\begin{array}{l}51.40 \\
(1.25)\end{array}$ & $\begin{array}{l}56.78 \\
(1.12)\end{array}$ & $\begin{array}{l}72.20 \\
(2.44)\end{array}$ & $\begin{array}{l}57.68 \\
(1.12)\end{array}$ & $\begin{array}{l}60.99 \\
(2.12)\end{array}$ \\
\hline PA & $\begin{array}{l}30.12 \\
(0.57)\end{array}$ & $\begin{array}{l}40.41 \\
(1.54)\end{array}$ & $\begin{array}{c}33.39 \\
(0.57 \\
)\end{array}$ & $\begin{array}{l}35.32 \\
(1.12)\end{array}$ & $0(0)$ & $\begin{array}{c}6.15 \\
(0.57)\end{array}$ & $0(0)$ & $\begin{array}{l}35.85 \\
(1.57)\end{array}$ & $\begin{array}{c}9.86 \\
(0.57)\end{array}$ & $\begin{array}{l}10.28 \\
(0.57)\end{array}$ \\
\hline $\mathbf{S A}$ & $\begin{array}{l}24.05 \\
(2.02)\end{array}$ & $\begin{array}{l}26.13 \\
(0.57)\end{array}$ & $\begin{array}{c}20.20 \\
(0.57 \\
\quad) \\
\end{array}$ & $\begin{array}{l}23.93 \\
(1.12)\end{array}$ & $0(0)$ & $\begin{array}{l}20.09 \\
(1.57)\end{array}$ & $0(0)$ & $\begin{array}{l}17.53 \\
(0.57)\end{array}$ & $0(0)$ & $\begin{array}{l}20.79 \\
(1.67)\end{array}$ \\
\hline
\end{tabular}

Many studies have ascertained that honey has antibacterial effects, which is due to its high values of osmolarity, as well as to low $\mathrm{pH}$, hydrogen peroxide content, and content of other, compounds still uncharacterized [15-16]. In some cases, the action of honey in inhibiting the growth of pathogenic microorganisms is caused by a low water activity of honey, but this is not the only explanation for its antimicrobial activity; infact, studying the effect of sugar syrups having the same water activity, it was found that they exhibit less strength as antimicrobial agents [17]. We studied different types of monofloral honey, some of them, such as the honey of tree of heaven, were never studied before under this viewpoint.

All types of honeys affected the formation of biofilm of Listeria monocytogenes, with percentage of inhibition up to $72.28 \%$, determined by the presence of $11.42 \mu \mathrm{l} / \mathrm{ml}$ of sulla honey, and never inferior than $24.17 \%$ (determined by the lavender honey). By the whole, the most resistant bacteria to the action of honey seemed S. aureus. This bacterium was resistant to the biofilm-inhibitory action of the honeys, with percentages not exceeding $26.13 \%$ (in the presence of the tree of heaven honey). $P$. aeruginosa exhibited an intermediate behavior, resulting sensitive to almost all types of honey, with a capacity to form biofilm decreasing at $40.41 \%, 35.85 \%$ and $35.32 \%$ in the presence of tree of heaven, sulla and ivy honey, respectively. The honey of strawberry tree showed its antibiofilm properties against Pseudomonas aeruginosa and St. aureus, and-mainly against St. aureus, similarly to results obtained by da Silva et al. [18]. At our knowledge, this was the first time wherein the activity of some types of honey, such as that of sulla and that of tree of heaven.

The behavior exhibited by the honeys to affect the metabolism of the cells present within the biofilm was opposite respect to the inhibitory effect on the biofilm formation. Thus, L. monocytogenes, which resulted the most sensitive to the action of all honeys, was conversely the most resistant to the action of the honeys to affect its metabolism, when the biofilm was formed, with percentages of inhibition not superior than $18.01 \%$. On the contrary, all honeys, although demonstrating less or no strength in inhibiting the formation of biofilm of $P$. aeruginosa and $S$. aureus, were more effective in inhibiting their metabolism, once the biofilm was formed. This could let us hypothesize that, in the 
case of L. monocytogenes the action of the honeys did not interest in particular the metabolism of the cells, only partially affected by the presence of the honey. On the contrary, the honeys, although less effective to inhibit the formation of biofilms of P. aeruginosa and S. aureus, were more effective in inhibiting the metabolism of their cells within the biofilm. This demonstrated once again the wide range of the ways of action of natural substances in fighting the pathogenicity of bacteria [1].

Table 2. Metabolic activity exhibited by the cells present within the bacterial biofilms in the presence of different volumes of the monofloral honeys. Results are reported as percentage of inhibition respect to the control (which $\%$ of inhibition was assumed $=0$ ). They are the mean $( \pm$ SD) of three experiments. TH: Tree of heaven honey; I: Ivy honey; L: Lavender honey; S: Sulla honey: ST: Strawberry tree honey. LM: Listeria monocytogenes; PA: Pseudomonas aeruginosa; SA: Staphylococcus aureus.

\begin{tabular}{ccccccccccc}
\hline $\begin{array}{c}\text { MTT } \\
\text { test }\end{array}$ & $\mathbf{T H}$ & $\mathbf{T H}$ & $\mathbf{I}$ & $\mathbf{I}$ & $\mathbf{L}$ & $\mathbf{L}$ & $\mathbf{S}$ & $\mathbf{S}$ & $\mathbf{S T}$ & $\mathbf{S T}$ \\
\% of inhibition & $\boldsymbol{\mathbf { L l }} / \mathbf{m} \mathbf{m}$ & $\mathbf{1 1 , 4 2}$ & $\mathbf{5 . 7 1}$ & $\mathbf{1 1 . 4 2}$ & $\mathbf{5 . 7 1}$ & $\mathbf{1 1 . 4 2}$ & $\mathbf{5 . 7 1}$ & $\mathbf{1 1 . 4 2}$ & $\mathbf{5 . 7 1}$ & $\mathbf{1 1 . 4 2}$ \\
\multirow{2}{*}{ LM } & 8.81 & 16.71 & 10.02 & 15.67 & 12.04 & 13.46 & 14.44 & 16.76 & 15.98 & 18.01 \\
& $(0.57)$ & $(1.13)$ & $(0.57)$ & $(0.57)$ & $(1.67)$ & $(0.57)$ & $(1.12)$ & $(1.12)$ & $(2.02)$ & $(0.57)$ \\
\hline \multirow{2}{*}{ PA } & 61.72 & 75.22 & 46.04 & 57.98 & 60.71 & 61.89 & 57.58 & 62.60 & 63.12 & 64.32 \\
& $(2.67)$ & $(1.57)$ & $(1.12)$ & $(1.67)$ & $(1.67)$ & $(2.01)$ & $(1.12)$ & $(1.40)$ & $(1.12)$ & $(1.44)$ \\
\hline \multirow{2}{*}{ SA } & 27.11 & 61.63 & 36.15 & 1.91 & 36.73 & 47.64 & 38.12 & 39.03 & 22.97 & 24.89 \\
& $(1.57)$ & $(1.67)$ & $(2.05)$ & $(0.03)$ & $(1.57)$ & $(2.02)$ & $(1.44)$ & $(1.67)$ & $(1.57)$ & $(1.12)$ \\
\hline
\end{tabular}

4. Conclusion

Clinical studies have ascertained the use of honey for several infected cutaneous woods, where it quickly clears the infection from the wound, improving tissue healing too. Several in vitro studies confirmed the wide-spectrum antimicrobial and antiviral properties of honey, due to several mechanisms [19]. The antimicrobial efficacy of honey is very depending on type of flower, region and season. We confirmed that not all honeys have the same antibacterial potency [20-21], and we are trying to biochemically characterize the honeys herein evaluated for their antibacterial activities. In each case, unlike the most conventional local drugs, honey does not lead to the development of antibiotic-resistant bacteria, and it may be used continuously.

Author Contributions: FN: VDF, RC: conceptualization. FN, AdA, FF, MNO, and LC: investigations. All authors contributed to writing and revising the manuscript. Funding: This research received no external funding.

Conflicts of Interest: The authors declare no conflict of interest.

\section{References}

1. Nazzaro, F.; Fratianni, F.; d’Acierno, A.; De Feo, V.; Ayala-Zavala, F.J.; Cruz, A.G.; Granato, D.; Coppola, R. Effect of polyphenols on microbial cell-cell communications. In: (G. Tommonaro ed.) Quorum Sensing, Academic Press, 2019, pp.195-223.

2. Lewis, K. Riddle of Biofilm Resistance. Antimicrobial Agents and Chemotherapy 2001, 45, 999-1007.

3. Boorn, K. L.; Khor, Y-Y; Sweetman, E.; Tan, F.; Heard, T. A.; Hammer, K.A. Antimicrobial activity of honey from the stingless bee Trigona carbonaria determined by agar diffusion, agar dilution, broth microdilution and time-kill methodology. J Appl Microbiol 2010,108,1534-1543.

4. Nassar,H.M.; Li,M.; Gregory, R.L. Effect of honey on Streptococcus mutans growth and biofilm formation. Appl Environ Microbiol 2012, 78, 536-540.

5. Merckoll, P.; Jonassen, T.O.; Vad, M.E.; Jeansson, S.L.; Melby, K.K. Bacteria, biofilm and honey: A study of the effects of honey on 'planktonic' and biofilm-embedded chronic wound bacteria. Scand J Infect Dis 2009, 41, 341-347.

6. Basson, N.J.; du Toit, I.J.; Grobler, S.R. Antibacterial action of honey on oral streptococci. J Dent Assoc S Afr 1994, 49, 339-341.

7. Majtan, J.; Bohova, J.; Horniackova, M.; Klaudiny, J.; Majtan, V. Anti-biofilm Effects of honey against wound pathogens Proteus mirabilis and Enterobacter cloacae Phytother Res 2014, 28, 69-75. 
8. Piotrowski, M.; Karpiński, P.; Pituch, H.; van Belkum, A.; Obuch-Woszczatyński,P. Antimicrobial effects of Manuka honey on in vitro biofilm formation by Clostridium difficile. Eur J Clin Microb Infect Dis 2017, 36, 1661-1664.

9. Jervis-Bardy, J.; Foreman, A.; Bray, S.; Tan, L.; Wormald, P.J. Methylglyoxal-infused honey mimics the antiStaphylococcus aureus biofilm activity of Manuka honey: potential implication in chronic rhinosinusitis. Laryngoscope 2011, 121,1104-1107.

10. Ansari, J.M.; Al-Ghamdi, A.; Usmani, S.; Al-Waili, N.S.; Sharma, D.; Nuru, A.; Al-Attal, Y. Effect of Jujube honey on Candida albicans growth and biofilm formation. Arch Med Res 2013, 44, 352-360.

11. Sarker, S. D.; Nahar, L.; Kumarasamy, Y. Microtitre plate-based antibacterial assay incorporating resazurin as an indicator of cell growth, and its application in the in vitro antibacterial screening of phytochemicals. Methods 2007, 42, 321-324.

12. O'Toole, G. A.; Kolter, R. Flagellar and twitching motility are necessary for Pseudomonas aeruginosa biofilm development. Mol. Microbiol. 1998, 30, 295-304.

13. Kairo, S. K.; Bedwell, J.; Tyler, P. C.; Carter, A.; Corbel, M. J. Development of a tetrazolium salt assay for rapid determination of viability of BCG vaccines. Vaccine 1999, 17, 2423-2428.

14. Fratianni, F.; Cozzolino, A.; De Feo, V.; Coppola, R.; Ombra, M. N.; Nazzaro, F. Polyphenols, antioxidant, antibacterial, and biofilm inhibitory activities of peel and pulp of Citrus medica L., Citrus bergamia, and Citrus medica cv. Salò Cultivated in Southern Italy. Molecules 2019, 24, 4577.

15. Molan, P.C. The antibacterial properties of honey. Chem. NZ 1995, 59, 10-14.

16. Khoo, Y.T.; Halim, A.S.; Singh, K.K.B.; Mohamad, N.A. Wound contraction effects and antibacterial properties of Tualang honey on full-thickness burn wounds in rats in comparison to hydrofibre. BMC Complement. Altern. Med. 2010,2010.

17. Molan, P.C. The antibacterial activity of honey. 1. The nature of the antibacterial activity. Bee World 1992, 73, 5-28.

18. da Silva, C.I; Aazza, S.; Faleiro, M.L.; Miguel, M.G.; Neto, L. The antibacterial, anti-biofilm, antiinflammatory and virulence inhibition properties of Portuguese honeys. J Apicult Res 2016, 55, 292-304.

19. Zafar, I.H. Antimicrobial properties of honey. Am J Therap 2014, 21, 304-323.

20. Kumar, P.; Sindhu, R.K.; Narayan, S., et al. Honey collected from different floras of Chandigarh Tricity: a comparative study involving physicochemical parameters and biochemical activities. J Diet Suppl. 2010, 7 , 303-313.

21. Kwakman, P.H.; Te Velde, A.A.; de Boer, L.; et al. Two major medicinal honeys have different mechanisms of bactericidal activity. PLoS One. 2011; 6:e17709.

Publisher's Note: MDPI stays neutral with regard to jurisdictional claims in published maps and institutional affiliations.

(C) 2020 by the authors. Submitted for possible open access publication under the terms and conditions of the Creative Commons Attribution (CC BY) license (http://creativecommons.org/licenses/by/4.0/). 